\title{
The Diary of Heinrich Witt and Autobiographical Writing in the Nineteenth Century*
}

\author{
Ulrich Mücke
}

The diary of Heinrich Witt is in many respects an exceptional document. There is no private diary known to scholars that was written in the $19^{\text {th }}$ century in Latin America and is similar in breadth to that by Heinrich Witt (1799-1892). ${ }^{1}$ Even in the $20^{\text {th }}$ and $21^{\text {st }}$ century, no private diary has been published in Latin America that is as extensive as Witt's unique text. ${ }^{2}$ The next most extensive Peruvian diary published after Witt is by Julio Ramón Ribeyro and is approximately one-fifth of the length that Witt achieved. ${ }^{3}$ Even for the European and AngloAmerican scene in respect to published diaries, Witt's is a huge text, although there are several very extensive published diaries. ${ }^{4}$

* Translated from the German by Bill Templer.

1 The designation "private diary" is intended to distinguish diaries that largely deal with the private life of the author from those writings that in the form of a diary or journal describe exclusively or almost exclusively political, military or other public events and conditions. One example of a huge political diary is: Carlos María Bustamante, Diario Histórico de México, 1822-1848, Mexico/City: CIESAS and El Colegio de México, 2001 and 2003 (ed. by Josefina Zoraida Vázquez and Héctor Cuauhtémoc Hernández Silva) (50 vols. on 2 CD-ROMs).

2 For a bibliographical listing of published egodocuments and self-narratives in and about Mexico, see Richard D. Woods, Autobiographical Writing on Mexico. An Annotated Bibliography of Primary Sources, Jefferson and London: McFarland \& Co., 2005; for a bibliography of published Latin American egodocuments and self-narratives from the $19^{\text {th }}$ century, see Catherine Aristizábal, Autodocumentos hispanoamericanos del siglo XIX. Fuentes personales y análisis histórico, Berlin et al.: LIT Verlag, 2012.

3 Julio Ramón Ribeyro, La tentación del fracaso. Diario personal, 1950-1978, Barcelona: Seix Barral, 2003 ( $1^{\text {st }}$ ed. 1992-1995).

4 A diary longer than that by Witt is for example the diary of Henri-Frédéric Amiel. But even the extensive diaries of the Brothers Goncourt, of Karl August Varnhagen von Ense, of Thomas Mann or Julien Green do not reach the textual length of the 10-volume diary of Heinrich Witt, which in the present edition consists of more than 18 million characters (with spaces, not including the appendices). The same is also true of the diaries of Johann Wolfgang von Goethe and Virginia Woolf, to mention but two further famous diarists. HenriFrédéric Amiel, Journal intime, Lausanne: Ed. L’Age d'Homme: 1976-1994 (12 vols.) (ed. by Bernard Gagnebin and Philippe M. Monnier); Edmond Goncourt and Jules Goncourt, Journal. Mémoires de la vie littéraire, Monaco: Éd. de la Imprimerie Nationale, 1956-1958 (22 vols.); Karl August Varnhagen von Ense, Tagebücher, Leipzig: Brockhaus, 1863-1870 
When Witt's diary is compared with other egodocuments and self-narratives, such as memoirs, autobiographical texts or political and military journals, within Peruvian history it is a striking achievement alone by its sheer length. ${ }^{5}$ The most extensive memoirs published in Peru after Witt are those by Luis Alberto Sánchez. His "personal testimony" published between 1979 and 1988 comprises six volumes, in length approximately half of the extant 10 volumes by Witt. ${ }^{6}$ The magnificent "anti-memories" by Alfredo Bryce Echenique are in two volumes. ${ }^{7}$ Several lengthy Latin American works of testimony and memory exceed the length of Witt's singular opus because they contain to a significant extent documents from the period, reproduced there, which supplement or replace the actual memoirs. ${ }^{8}$ Other Latin American authors have published several autobiographical works which taken together come close in length to the extant ten volumes of Heinrich Witt's diary. ${ }^{9}$ If we include letters in the autobiographical writings, then the Mexican writer Alfonso Reyes achieved a collection of extant autobiographical texts similar in volume to that of Heinrich

(14 vols.) (ed. by Ludmilla Assing); Thomas Mann, Tagebücher, Frankfurt/M.: Fischer, 19771995 (10 vols.) (ed. by Peter de Mendelssohn and Inge Jens); Julien Green, Journal, Paris: Plon, Le Seuil, and Flammarion, 1938-2006 (19 vols. with different titles); Johann Wolfgang von Goethe, Tagebücher. Historisch-kritische Ausgabe, Stuttgart et al.: Metzler, 1998-2014 (26 vols., to date 14 vols. published) (ed. by Wolfgang Albrecht and Jochen Golz); see also: Johann Wolfgang von Goethe, Sämtliche Werke, Frankfurt/M.: Deutscher Klassiker Verlag, 1985-2013 (45 vols.) (ed. by Hendrik Birus et al.); Virginia Woolf, The Diary of Virgina Woolf, London: Hogarth, 1977-1984 (5 vols.) (ed. by Anne O. Bell).

5 On the literature published up until 1971, see Jorge Basadre, Introducción a las bases documentales para la historia de la República del Perú con algunas reflexiones, Lima: P. L. Villanueva, 1971 (2 vols.).

6 Luis Alberto Sánchez, Testimonio personal. Memorias de un peruano del siglo XX, Lima: Villasan and Mosca Azul, 1969-1988.

7 Alfredo Bryce Echenique, Permiso para vivir. Antimemorias 1, Lima: Peisa, 2005 ( $1^{\text {st }}$ ed. 1993); idem, Permiso para sentir. Antimemorias 2, Lima: Peisa, 2005.

8 Victoria Ocampo, Autobiografía, Buenos Aires: Sur, 1979-1984 (6 vols.); idem, Testimonios, Madrid and Buenos Aires: Revista de Occidente, Sudamericana and Sur, 1935-1977 (10 vols.); Daniel F. O'Leary, Memorias del General O'Leary, Caracas: Ministerio de Defensa, 1981 (34 vols.).

9 Probably best known are the various autobiographical writings by José Vasconcelos. Writing from a different political position, Andrés Iduarte left a similarly heterogeneous and voluminous ensemble of egodocuments. See also the various memoirs by Francisco Luis Urquizo, which tell, in part in a fictionalized form, about his military and political career. Richard D. Woods, Autobiographical Writing on Mexico. 
Witt. ${ }^{10}$ But if we look for an extensive cohesive text of an autobiographical nature centered on the life of the author, there is to date no known similarly voluminous work from Latin America like that of the extant diary of Heinrich Witt. ${ }^{11}$

Heinrich Witt's diary is not only exceptional by dint of length but also in respect to the period of time described there and the duration of its genesis. There is no Peruvian egodocument based on the experience of the author that deals with a period of nearly 90 years. This is unusual both in a Latin American and global nexus of comparison, since hardly anyone over the age of 90 is still able to write about himself or herself. Since according to his own statements, Witt made use of notes and logs from past years when writing the diary available to us, the period of actual hands-on composition is likewise unusually long. ${ }^{12}$ Witt worked on the existing version from 1859 to 1890 . If one keeps in mind that he used notes and records he kept stemming from the earlier 1820s, then Witt was engaged with writing the text we are familiar with today for a total of some 70 years. By comparison, Julio Ramón Ribeyro labored on his great literary diary for just under 40 years.

Even if Witt's diary is in many respects a unique document, it nonetheless cannot be properly understood without viewing it in the traditions of writing of its time. Heinrich Witt was not just a very industrious and committed diarist, he also composed countless letters, wrote reports (for example, as a consul, a commercial clerk and an independent businessman) and kept the account books of a number of firms during the course of his long life. In addition, since early childhood Witt was an enthusiastic reader: his interests ranged from historical and geographical literature to belles lettres, and he also was an avid reader of newspapers and magazines. The present paper seeks to evaluate, classify and place his work in context. It then discusses the implications of

10 On the autobiographical writings of Alfonso Reyes, see RichardD. Woods, Autobiographical Writing on Mexico, pp. 187-189 and Alfonso Reyes, Obras completas, Mexico/City: Fondo de Cultura Económica, 1955-1993 (26 vols.). In Peru there are only a small number of known larger collections of private letters; noteworthy in particular is: José de la Puente Candamo and José de la Puente Brunke (eds.), El Perú desde la intimidad. Epistolario de Manuel Candamo (1873-1904), Lima: Pontificia Universidad Católica del Perú, 2008 (807 pp.).

11 Even the 10-volume work by Nemesio García Naranjo is substantially smaller in textual length than the extant volumes of Witt's diary. Nemesio García Naranjo, Memorias, Monterrey: Talleres de 'El Porvenir', 1966 ( $2^{\text {nd }}$ ed., with various subtitles).

12 On the genesis and form of the diary, see Christa Wetzel, History of the Diary of Heinrich Witt (in this volume); idem, Form and Content of the Diary (in this volume). 
such a positioning of Witt's text in the $19^{\text {th }}$ century for the historical utilization and interpretation of this document.

\section{Form of the Diary}

The first question arising in an analysis of Witt's voluminous text is whether this is actually a diary. Witt himself speaks of a diary, but he also calls the text a chronicle. ${ }^{13}$ Speaking against classifying the text as a diary is in particular one key fact:Witt did not write most of the text simultaneously or nearly so with the time it describes but rather in part some decades later. In addition, substantial passages in the text are not in keeping with the form of a diary or journal, i.e are not ordered as dated entries. In the view of Philippe Lejeune and Catherine Bogaert, these two elements suffice to make the text an autobiography:

An emendated or later revised and expanded diary will perhaps gain in literary value, but it will forfeit what is decisive, namely the authenticity of the moment. At the stroke of midnight, I mustn't change anything more. If nonetheless I do, I depart from the diary and lapse into autobiography. ${ }^{14}$

Of course, we can object to such a narrow definition, noting that the "diary is characterized by its hybridity and diversity (it is a mixed bag)."15 According to Rebecca Steinitz, that was precisely the case for the British diary in the $19^{\text {th }}$ century:

For men and women alike, the diary's totalizing yet elastic temporal and spatial conventions enabled the enactment of Enlightenment observation and organization, Romantic interiority, Evangelical and secular selfimprovement, Victorian domesticity, and imperial geographies and ethnographies. ${ }^{16}$

13 On this in detail, see also Christa Wetzel, History of the Diary of Heinrich Witt.

14 Philippe Lejeune and Catherine Bogaert, Le journal intime. Histoire et anthologie, Paris: Textuel, 2006, pp. 23f. Compare the similar definition in Ralph-Rainer Wuthenow, Europäische Tagebücher. Eigenart. Formen. Entwicklung, Darmstadt: Wissenschaftliche Buchgesellschaft, 1990, p. 2.

15 Rachel Cottam, "Diary," p. 268, in: Margareta Jolly (ed.), Encyclopedia of Life Writing. Autobiographical and biographical forms, pp. 267-269.

16 Rebecca Steinitz, Time, Space, and Gender in the Nineteenth-Century British Diary, New York: Palgrave Macmillan, 2011, p. 2. 
Likewise when we look at the great German diaries of the $19^{\text {th }}$ century, the mixing of the genre appears to have been not uncommon. The diary of Ferdinand Beneke (1774-1848), for example, contains travel diaries written for larger groups, drafts of text published in magazines and also private notes written in a secret script. ${ }^{17}$ The hybrid character of the diary also involves the temporal point of composition, because more frequently than Lejeune and Bogaert assume, diaries are not written until later on post factum, and wrought into their final form based on older notes. Thus, a characteristic of great diaries would appear to be that they specifically break through the strict definition of the diary, utilizing various text forms scattered over an extended period of time. But this also means that Heinrich Witt's diary should be classified within very different traditions and conventions of writing. That is because Witt's diary is marked by his reading of very different sorts of texts and Witt's composition extending over several decades of a range of very diverse written texts. Consequently, this diary should be positioned not only within the history of diary writing but also in the history of travel literature, autobiographical writing, memoirs and biographical and historical literature.

\section{The Cultural Location}

Witt's practices of reading and writing were to a great extent international. He read seven languages (German, English, French, Spanish, Italian, Danish, Latin) and wrote in four or five (German, English, French, Spanish, Danish). If one examines the culture that marked Witt's writing, at least three language areas must be mentioned: the German, the British and the Spanish-Peruvian. By contrast, French writing traditions were only a weaker influence on Witt's composition. Ultimately he also never lived for any longer stretch of time in France, while he spent the greater part of his life in Altona, London and Lima. Thus, there is good reason to view the diary as a hybrid cultural product. But in this regard, most specifically the Peruvian influence should not be underestimated. It is true that in his aesthetic credo and statements, he was oriented to what was considered European high culture in the $19^{\text {th }}$ century. But the reality of the everyday reading culture in Lima was marked to a significant extent by published materials of all kinds appearing in the Peruvian capital. Consequently, Witt's diary is marked by a probably unique hybrid combination of German, English and Peruvian elements. German was Witt's mother tongue and he had been socialized as a child and youth in the German-speaking

17 Frank Hatje et al., Ferdinand Beneke (1774-1848). Die Tagebücher. Begleitband zur ersten Abteilung "Bürger und Revolutionen," Göttingen: Wallstein, 2012, pp. 11f. and 25. 
environment. English was the language of the diary and of the then mightiest nation in the world in Witt's eyes. Finally, Spanish was the language of the everyday reality, not only oral, that surrounded and influenced Witt as he composed his diary, a reality that he described, naturally and extensively. Thus, if we ask to what extent the diary was marked and influenced by the writing cultures of the $19^{\text {th }}$ century, it is necessary to deal with writing principally in three countries: Germany, Great Britain and Peru.

\section{Diary Traditions}

If one understands the diary as the regular noting and recording of thoughts and observations, then diaries qua genre can be found in numerous cultures of writing dating back thousands of years. In Europe, Meditations by Marcus Aurelius has been designated as the first quasi-diary-like text. ${ }^{18}$ But outside Europe as well, there were and are numerous traditions of the regular recording of thoughts and observations by individuals. The writing of diaries became a widespread practice among the educated in many regions of Europe in the course of modernity. The $19^{\text {th }}$ century is considered the era, at least in Great Britain, when "the diary [...] flourished as never before."19 This can be substantiated both through the multitude of extant diaries in manuscript form and the many blank booklets and notebooks that were sold as commodities so that their buyers could write down their entries. A diary was no longer the result of regular writing, it was an acquirable product with specific characteristics, such as one can purchase as a "diary" down to today: not the already written text composed by someone else but rather sheets of paper stapled or bound together that are largely or completely blank.

The upsurge in diary writing was also manifested in the fact that beginning from the $18^{\text {th }}$ century, private diaries were also published. This led to a market in which there were not only descriptions in diary form about distant lands, unfamiliar regions and outstanding political events but likewise texts that to a significant extent reported on the everyday events and realities of life. Thus, for example, in 1771 Johann Caspar Lavater published his Geheimes Tagebuch. Von einem Beobachter Seiner Selbst. While Lavater's diary at least was still reporting on contemporary everyday life, Samuel Pepys' diary sparked a sensation after 1825 , although the period of time it was reporting on lay some 150 years in the

18 Wuthenow, Europäische Tagebücher, p. 2.

19 Steinitz, Time, Space, and Gender, p. 3. 
past. ${ }^{20}$ And since just shortly before that another diary from the $17^{\text {th }}$ century, John Evelyn's Diary, published in 1818, had found numerous eager readers in Great Britain and beyond, the diary appears at this point in time to have won over devotees likewise as a medium for instruction on and information about past realities of everyday life. ${ }^{21}$ The establishment of the diary as a bona fide literary genre also was ultimately manifested in the $19^{\text {th }}$ century by the fact that diaries of literary writers began to see the light of publishing day, possibly in order to provide additional evidence of their literary creativity. ${ }^{22}$

We can safely assume that in Peru as well as other Latin American countries in the $19^{\text {th }}$ century, numerous diaries were written. However, what is extant and has survived in Peru are only a small number of travel diaries and several political diaries. By contrast, we know of no private diaries from Peru in the $19^{\text {th }}$ century describing everyday life and matters of personal family events and observations. ${ }^{23}$ Yet there certainly are a number of private diaries in existence from other Latin American countries. However, most of these were not published until the $20^{\text {th }}$ century. ${ }^{24}$

Thus, if Witt appropriated certain stimuli for his own practice as a diarist from other diaries, these most probably were texts in English or German. But it is difficult to determine the extent to which Witt was directly influenced by such texts. Witt makes no mention of well-known diarists such as Lavater, Pepys, Hebbel or Evelyn. He does include numerous remarks on his own writing as a diarist. But these are often causal in nature and we cannot deduce from them any more profound confrontation on his part with the whole question of diary writing or any intensive reading of other diaries. In this respect, at least in the German-speaking and English-speaking area, Witt was probably a quite typical diarist. His diary writing was a practice he engaged in without any theoretical-methodological foundation or a more probing study of the genre.

20 Johann Caspar Lavater, Geheimes Tagebuch, Leipzig: Weidmann u. Reich, 1771-1773 (2 vols.); Samuel Pepys, The Diary of Samuel Pepys. A New and Complete Transcription (ed. by Robert Latham), London and Berkeley (Cal.): Harper Collins and University of California Press, 2000 (11 vols.) ( $1^{\text {st }}$ ed. 1825). Lavater's work was published in London in 1795 in English translation as Secret journal of a self-observer: or, Confessions and familiar letters of the Rev. J. C. Lavater, trans. by Rev. Peter Will. Online: https://archive.org/details/ secretjournalofsollava.

21 John Evelyn, Memoirs, illustrative of the life and writings ..., London: Colburn and Arch, 1818 (2 vols.).

22 For example, Friedrich Hebbel, Tagebücher, Berlin: Grote: 1885-1887 (2 vols.); Johann Wolfgang von Goethe, Tagebücher, Weimar: Boehlau, 1887-1903 (13 vols.).

23 See Basadre, Introducción a las bases documentales.

24 See Woods, Autobiographical Writing; Aristizábal, Autodocumentos hispanoamericanos. 


\section{Privacy}

To call Witt's text a private diary can lead to misunderstandings, since there can be quite different interpretations of the terms "private" and "intimate." The very fact that Lavater calls a text he publishes "intimate" points up the problematic nature of these concepts. ${ }^{25}$ That is because the French term "journal intime" and the German "privates Tagebuch" do not mean to suggest that intimate matters that no other person should know are being reported on. On the contrary: as a rule, diaries were and continue to be written for others. They are presented to or read aloud to others so that they can gain some idea about the thought and life of the diarist. Witt himself says at many points in his diary that it is meant for posterity. "Private" and "intimate" thus do not mean secret, and in many cases they do not mean that the text is not meant for the public to read. A private diary by a literary writer is frequently also not composed solely for a small circle of potential readers but for a large readership. Consequently, "private" and "intimate" mean that the diary reports about private matters and thoughts. The private/intimate diary deals also or indeed primarily with the private life of the writer, contrasting with diaries that foreground a military undertaking, political campaigns or other public questions and events. Thus, the private and intimate diary comes into being precisely in an era when the separation between the private and public spheres is taking on new significance. Only when a "public sphere" arises can a "private sphere" also spring into existence. And only at that juncture in time can there be text genres which are principally reserved for one of these two spheres. Witt's diary does report in detail about political, historical and social developments and events, but it also reports on the private life of the author. It is thus likewise a private diary, but not only a private diary. Witt expresses at different points the view that he perceives himself as someone who is not principally on the stage of public life. Thus, for example, the entry for 29 July 1888 reports on a visit with an acquaintance from Lima upper class: "she was very polite, extremely glad to see me." But when another guest enters, she no longer pays any attention to Witt: "[Later] I was told that the gentleman was Francisco Garcia Calderon, who, as everybody knows, has acted a conspicuous part in Peruvian politics, and is likely to do so again; whilst I am, and always shall be, nothing better than simple Henry Witt."26

25 This note also in Hatje et al., Ferdinand Beneke (1774-1848). Die Tagebücher, p. 11.

26 Heinrich Witt, Diary, vol. 10, p. 364. 


\section{Bookkeeping and Confession}

According to Philippe Lejeune, the "diary, like writing itself, was born of the needs of commerce and administration."27 He notes that before the genesis of private diaries, there were account books in which transactions and sums were regularly recorded. In his view, the private diaries correspond to these account books in that at regular intervals, notes were also written down that served to recall and show in the balance, as it were, various things that had transpired. However, Lejeune does not describe how and when this transition presumably took place. He likewise does not mention any intermediary forms between commercial account books and private diaries. Witt was engaged with both genres. As a commercial employee and an independent businessman, he kept ledgers over many decades, so that in parallel he maintained both accounting books and private diaries. But by that juncture the two genres had drifted so far apart that it is difficult to determine any direct mutual influence. ${ }^{28}$ In the $19^{\text {th }}$ century, fixed written systems for accounting already existed, and Witt probably also followed these in a relatively rigid manner.

As a rule, research on the history of the diary stresses more the importance of religion than the commercial tradition of maintaining regular accounts. Ralph-Rainer Wuthenow thinks that the diary "secularizes and liberates the confession [...] for self-exploration."29 In regard to continental Europe, as a rule the role of Pietism is emphasized in particular as relevant for the history of the diary since the $16^{\text {th }}$ century. That is because diary writing was a procedure that facilitated in almost ideal fashion the self-reflection and self-critique that Pietism called for. "Of great importance was the practice of looking deeply within oneself, the observation of one's own thoughts and actions [...] Because it sharpened and refined more generally the view for seeing internal mental events, subjecting not only actions but their interior motivation to selfscrutiny." ${ }^{30}$ For that reason, it is no accident that diary writing was especially widespread in areas with a strong Pietistic influence. By contrast, when it comes to Great Britain and North America, the importance of Puritanism has

27 Philippe Lejeune, On Diary, eds. Jeremy D. Popkin and Julie Rak, Honolulu: University of Hawaii, 2009, p. 51.

28 On the history of merchant's books, see Markus A. Denzel, Jean Claude Hocquet, Harald Witthöft (eds.), Kaufmannsbücher und Handelspraktiken vom Spätmittelalter bis zum 20. Jahrhundert. Merchant's Books and Mercantile Practice from the Late Middle Ages to the Beginning of the $20^{\text {th }}$ Century, Stuttgart: Steiner, 2002.

29 Wuthenow, Europäische Tagebücher, p. 13.

$30 \quad$ Hatje et al., Ferdinand Beneke (1774-1848). Die Tagebücher, p. 20 
been stressed, because similar to Pietism, the Puritans accorded a significant role to the internal self-questioning of the individual believer. ${ }^{31}$

In his diary, Witt does not describe himself as being an extremely religious person, but the self-criticism and moralizing description of his fellow human beings that he practices in his diary at least suggest the possible presence of a religious heritage. Witt was also socialized in religious terms in certain frameworks. He had been baptized and confirmed as a Lutheran, his mother stemmed from a Mennonite family, a cousin joined the Catholic Redemptorist order, another was a Protestant pastor. ${ }^{32}$

Even if Witt criticizes Catholicism at various points in his diary and apparently was unfamiliar with Catholic diaries from the colonial period, it is at least worth mention here that there was also an early modern tradition of the religious diary in Spanish America as well. Known today from Peru, in particular is the diary of the Afro-Peruvian Ursulá de Jesús (1604-1666), in which she describes her life and spiritual experiences in a convent. ${ }^{33}$ So one should not look solely to Protestantism in connection with the question of the importance of religion for the history of the diary. Even if Catholicism had a different influence on writing practices, both denominations developed stimuli for diary writing, which even had a certain impact on individuals who were critical of religious beliefs like Heinrich Witt.

\section{Travel Diaries}

Contrasting with the tradition of the religious diary, the influence of travel literature is abundantly clear in Witt's diary. His diary is actually in large part a travel diary. The first two volumes describe in great detail trips through Peru and Bolivia, and volumes 2 to 6 and as well as Vol. 9 contain long descriptions of the various trips that Witt took to and through Europe. Of the extant ten volumes, only three contain no reports on his travels, at least if one excludes

\footnotetext{
$31 \quad$ Lejeune and Bogaert, Le journal intime, p. 91.

32 On the life history of Heinrich Witt, see Christa Wetzel, A Short Biography of Heinrich Witt (in this volume).

33 Nancy E. van Deusen (ed.), Las almas del purgatorio. El diario espiritual y vida anónima de Úrsula de Jesús, una mística negra del siglo XVII, Lima: Pontificia Universidad Católica del Perú, 2012; for an English translation of the diary see: idem (ed.), The Souls of Purgatory. The Spiritual Diary of a Seventeenth-Century Afro-Peruvian Mystic. Ursula de Jesús, Albuquerque: University of New Mexico Press, 2004. On Spanish America, see Kristine Ibsen, Women's Spiritual Autobiography in Colonial Spanish America, Gainesville: University of Florida Press, 1999.
} 
his various periods of stay in the country house in nearby Chorrillos. One can speculate to what extent travel was a central motive driving Witt's writing as a diarist, because while in his travelogues he describes in great detail what he experienced and saw, thus underlining its importance, in connection with the narratives about his life in Lima, he often stresses that this life was humdrum and uninteresting.

In the eyes of Ralph-Rainer Wuthenow, travel diaries are not diaries in the narrower specific sense, but rather belong, aside from some exceptions, to the genre of travelogues. That is because, as he argues, their principal purpose is the description of the trip and what was seen and experienced while traveling. ${ }^{34}$ Philippe Lejeune begs to differ on this point: he regards both the log books kept at sea for thousands of years as well as travelogues as the root source for the travel diaries, and those diaries in turn constitute in his view a preform of the private diary. ${ }^{35}$ Unquestionably, travelogues have been written for thousands of years in various different forms and the reading of travel diaries since the Early Modern Era has enjoyed growing popularity, so that an ever greater number of such texts were published. ${ }^{36}$

It was not only Europe where travel and the writing of travelogues and descriptions of trips or travel diaries were considered a special proof of culture and cultivation. After independence, numerous travelogues were written and published in Latin America. ${ }^{37}$ Peru was no exception in this regard. However, during Witt's lifetime, only three of the Peruvian travelogues or travel diaries known today had been published. In 1845, Juan Bustamante brought out Viaje al antiguo mundo, in which he described his trip through Europe. In 1862, the Recuerdos de viaje a los Estados Unidos by José Arnaldo Márquez was published in Lima, and at the beginning of the 189os, Pedro Paz Soldán y Unanue published sketches and memoirs in the newspaper El Chispazo about his long stay in Europe and the trips he took there. ${ }^{38}$ Common to all three authors was their view that their reports would serve as a contribution to the ongoing internal Peruvian discussions about the development of the country.

\footnotetext{
34 Wuthenow, Europäische Tagebücher, pp. 165f.

35 Lejeune u. Bogaert, Le journal intime, pp. 56-59.

36 Peter J. Brenner (ed.), Der Reisebericht. Die Entwicklung einer Gattung in der deutschen Literatur, Franfurt/M.: Suhrkamp, 1989.

37 Aristizábal, Autodocumentos hispanoamericanos, pp. 145-165.

38 Juan Bustamante, Viaje al antiguo mundo, Lima: Masías, 1845 ( $2^{\text {nd }}$ ed.); José Arnaldo Márquez, Recuerdos de viaje a los Estados Unidos de América del Norte (1857-1861), Lima: Imprenta del "Comercio", 1862 ( $2^{\text {nd }}$ ed., Lima: Universidad Nacional Mayor de San Marcos und Corporación Financiera de Desarrollo, 2003); Pedro Paz Soldán y Unanue, Memorias de un viajero peruano, Lima: Biblioteca Nacional del Perú, 1971.
} 
Europe and the United States served as a model for what should be changed in Peru and what was worth being retained and preserved. The authors also wished to show by means of their reports that they had the necessary political experience in order to properly assess political projects in Peru. ${ }^{39}$

It is unclear whether Witt knew the texts by the Peruvians. His diary made no mention of them. But since he read newspapers a great deal and also owned books published in the country, it is quite likely that he was familiar with these travelogues. He knew at least one of the authors personally, Pedro Paz Soldán Unanue, and mentioned him several times in the diary.

Two travellers who appear a number of times in Witt's diary and whom he considered both a positive and negative reference are Alexander von Humboldt and Flora Tristán. It is true that Witt criticized Humboldt's travel narratives, saying they "did not answer my expectations." Yet at the same time he concurred in the same passage with Humboldt's characterization of travel accounts: "When objects are only known to us through the relation of travellers, they excersise a peculiar charm, our imagination is interested in all that is vague and undefined, the enjoyments of which we do not partake, appear to be preferable to those which are at hand in the narrow circle of a quiet (sedentary) life." 40 One might conclude that both for European and Peruvian readers, the charm of Witt's diary lay precisely in his description of the unknown - because Witt described, after all, both worlds.

Witt expressed his criticism of an overly pronounced literary rendering or even fictionalizing of the travelogues. In commenting on Flora Tristán, he notes:

For light reading we had taken up "Les Pérégrinations d'une Paria", by Flora Tristan, who gave an account of her visit to Perú. It was a most flimsy production, upon which not the slightest reliance could be placed. She depicted everything in strong colours whether true or not, only for the sake of effect. She painted herself as the most sensible of females, at the same time of a proud, bold, and noble character; the society of Arequipa, of which she could not know much, as the ne plus ultra of stupidity, excepting one or two ladies of her family, and three or four foreigners. ${ }^{41}$

39 Ulrich Mücke, "Autobiographisches Schreiben und Kolonialismus in Peru," in: Hans Medick, Angelika Schaser, Claudia Ulbrich (eds.), Selbstzeugnis und Person. Transkulturelle Perspektiven, Cologne et al.: Böhlau, pp. 201-225.

40 Heinrich Witt, Diary, Vol. 1, p. 671. Translated by Heinrich Witt.

41 Heinrich Witt, Diary, Vol. 9, pp. 259f. See also Witt's remarks concerning Flora Tristán in Heinrich Witt, Diary, Vol. 2, p. 854. 
Witt evidently expects more respect to be shown here for the hometown of his deceased wife, who came specifically from those circles that Witt believes are not properly described here. Quite apart from who sketched an accurate picture of the Arequipa upper crust, Witt formulates here the criteria for his own writing in confrontation with another travel account: it was his claim that his diary must not judge anything without a good knowledge of the object, and Witt must likewise not sketch himself in colors all too rosy.

Witt doubtless knew more travelogues and travel diaries than these. ${ }^{42}$ But the two examples can suffice to show that Witt wrote his diary aware of and in debate with travel accounts and travel diaries penned by others. Specifically the fact that Witt proceeded in 1859 to completely rewrite his diary can serve as evidence for the conjecture that he had a clear conception of the kind of diary he was writing and to what end, and what sort of diary he did not wish to leave to posterity.

\section{Writing History}

In her standard work on Spanish-American autobiographic writing, Sylvia Molloy emphasizes that Spanish-American egodocuments and self-narratives have to a significant extent been written for the public. She suggests that the authors viewed themselves as eye-witnesses of their time and in this capacity, wished on the one hand to describe their times, and on the other to communicate to the general public that they had been or still were useful members of their society. ${ }^{43}$ Since Rebecca Steinitz has also shown in the case of Great Britain that egodocuments and autobiographical texts in the course of the $19^{\text {th }}$ century increasingly targeted a public readership, we can debate the extent to which the great importance of the public sphere distinguishes the history of Latin American egodocuments and self-narratives from that of the European or Anglo-American autobiographical texts. In any case, it is striking how comparatively small the number is of autobiographical texts known to us from Latin America that were not clearly intended for a smaller or larger public.

In any event, Heinrich Witt wrote his diary in an era in which both in Latin America (including Peru), Europe and Anglo-America, it was customary to

42 See, for example, the quotation from Johann Wolfgang von Goethe's "Campagne in Frankreich," the autobiographical report of a trip and/or military campaign. Heinrich Witt, Diary, vol. 3, p. 292.

43 Sylvia Molloy, At Face Value. Autobiographical Writing in Spanish America, Cambridge et al.: Cambridge University Press, 1991, pp. 8-10. 
write autobiographical texts for a public readership. Memoirs, autobiographies, diaries or reports and justifications composed in the ego-form were everywhere part of the public debate about the present and past. Statesmen, artists and other figures from public life published egodocuments and self-narratives in a bid to influence how subsequent generations might see their person and their time. The upswing in the literature of remembrance went hand in hand with a changing understanding of history. This was fostered inter alia by the discipline of historiography then emerging in the $19^{\text {th }}$ century. In the eyes of many, history, and not religion, now appeared to be the key for explaining the present. The historical sciences postulated that understanding the past was only possible through the study of documents extant from the past. What could be more appropriate than to influence the view of the future on one's own time by creating such documents? The historical sciences in the $19^{\text {th }}$ century were also bound up with the boom in the literature of remembrance written for the public, since historiography attributed a leading role to great men in shaping the course of history, and generally espoused an image of humanity that postulated and celebrated self-determination and the independence of the male, European (or European-derived) individual. ${ }^{44}$

With his strong interest in history and historiography, Heinrich Witt was a child of his time. In the course of his life, he read innumerable historical romances and novels, scientific-historical works, biographies and memoirs of important historical personalities. His preference was for German and English authors, while he rarely mentions the small number of texts published in Peru on Peruvian history. Thus, for example, he lavishes praise on Prescott's History of the Conquest of Peru, while Sebastián Lorente's Historia de la conquista del Perú published in Lima in 1861 receives no mention whatsoever. ${ }^{45}$ That is also the case when it comes to all the other works of this Spanish-Peruvian historian, even though Witt knew him personally from other contexts. ${ }^{46}$ Only Ricardo Palma is mentioned more frequently. Witt was familiar with his Tradiciones peruanas (although he mistakenly referred to the work as Leyendas peruanas) and now and then makes mention of historical sketches, depictions and expositions that Palma published in the Lima newspapers. ${ }^{47}$

44 On the history of historiography, see Georg Iggers, Supriya Mukherjee, Q. Edward Wang, A Global History of Modern Historiography, Harlow et al.: Pearson Longman, 2008.

45 Heinrich Witt, Diary, Vol. 8, p. 331.

46 The great historical-biographical dictionary of Manuel Mendiburu mentions Witt only once, but praises the diary as "very interesting and valuable." Heinrich Witt, Vol. 10, p. 290. Manuel de Mendiburu, Diccionario histórico-biográfico del Perú, Lima: Solís u. Bolognesi, 1874-189o (8 vols.).

Heinrich Witt, Diary, Vol. 10, pp. 108, 168. 
Likewise when it came to biographies and memoirs, Witt preferred European authors. He read biographies of important statesmen, such as Bismarck and Gneisenau, as well as memoirs, such as those by Napoleon and Marie Antoinette. For Peruvian history, he refers in a number of places to the memoirs of William Miller published in 1828-1829, a British officer who had fought in the wars for independence on the side of the insurgents. ${ }^{48}$ The memoirs and justificational writings and self-vindications by Peruvians and Witt's contemporaries, such as Juan Gualberto Valdivia and Manuel Atanasio Fuentes, are by contrast not mentioned, even though Witt was personally acquainted with Fuentes.

Nonetheless, one must proceed on the assumption that Witt regularly read small biographical sketches or autobiographical self-vindications published in the Lima press. That is because the newspapers published such sketches in their obituaries, and persons who wished to justify themselves in response to accusations published extensive reports about themselves and their actions. ${ }^{49}$ So if one also looks to the papers, the biographical and autobiographical texts that Witt was reading regularly were not only of European origin. Since over many decades, Witt was an avid reader of biographical and autobiographical narratives of all different kinds, from all eras and in a number of different languages, it is highly likely that his own text, which he wrote after all explicitly for posterity, was influenced by this extensive reading. ${ }^{50}$ Even if Witt describes himself as a private individual who had no public importance, on the basis of his reading it was very probably clear to him just how strongly his own work could influence the view of future generations looking back not only at him but at his family and his times.

\section{How to Read the Diary of Heinrich Witt}

In his 1971 Introducción a las bases documentales para la Historia de la República del Perú, Jorge Basadre writes that Heinrich Witt's diary contains "rich first-hand information on the social, economic and political life of Peru." For that reason, he deemed the diary as a work of "inestimable value." ${ }^{51}$ Yet

\footnotetext{
48 Heinrich Witt, Diary, Vol. 9, pp. 78, 88, 111.

49 One example worth mentioning is the short biography of José Rufino Echenique, published after his death in the newspaper El Comercio; it was commented on in detail by Witt. Heinrich Witt, Diary, Vol. 10, p. 169.

5o Regarding Witt's wish that his diary be read by posterity, see Christa Wetzel, History of the Diary of Heinrich Witt.

51 Basadre, Introducción a las bases documentales, vol. 1, p. 103.
} 
historiography to date has not made use to any substantial extent of the diary. The original is privately owned and is thus relatively difficult to access. The published extracts of the diary are translations, so that without knowledge of the original it is often unclear to what extent these translations constitute a scientifically usable rendition of the original text by Witt. ${ }^{52}$ But even when one has Witt's original in hand, the question still remains: to what extent can the reader trust Witt's statements, and where should doubts arise? One should not take Basadre's judgment as suggesting that we should view all of Witt's statements without exception as credible information. How then should one deal with a diary that over several decades was repeatedly emendated and revised, and consciously composed with a view to posterity?

In the more than four decades since Basadre's judgment on the worth of Witt's diary, how historians deal with egodocuments and self-narratives has changed considerably. On the one hand, for quite a long time now diaries, memoirs, autobiographies, letters and other egodocuments have been experiencing a veritable boom in historical research. On the other, a debate has emerged as to whether this type of source requires a specific manner of reading and interpretation. ${ }^{53}$ The upsurge in egodocuments and selfnarratives utilized in the historical sciences is closely interlinked with the "cultural turn" in scholarship in recent decades. A central element in this turn is the assumption that depictions of the present and past should not be viewed as a reflection of a text-external reality but rather as an interpretation of that reality. ${ }^{54}$ Thus, the sources historians work with do not reflect how "it actually was," ${ }^{55}$ but rather how the author of a specific text or artifact was able to understand and describe it. Sources are determined and shaped culturally, linguistically and historically: their determinate nature also means that the antagonism between facts and fiction, previously thought to be a radical divide, has been soften and blurred. In historiography this means that

$5^{2}$ Heinrich Witt, Diario y observaciones sobre el Perú (1824-189o), Lima: Corporación Financiera de Desarrollo, 1987; idem, Diario. 1824-189o. Un testimonio personal sobre el Perú del siglo XIX, Lima: Banco Mercantil del Peru, 1992 (2 vols.).

53 For a survey, see Hans Medick, Angelika Schaser, Claudia Ulbrich, "Selbstzeugnis und Person. Transkulturelle Perspektiven," in: idem (eds.), Selbstzeugnis und Person. Transkulturelle Perspektiven, Cologne et al.: Böhlau, 2012, pp. 1-20; Sidonie Smith and Julia Watson, Reading Autobiography. A Guide for Interpreting Life Narratives, Minneapolis and London: University of Minnesota Press, 2001.

54 On the "cultural turn," see Doris Bachmann Medick, Cultural turns: Neuorientierungen in den Kulturwissenschaften, Reinbek bei Hamburg: Rowohlt, 2006.

55 Leopold von Ranke, Geschichten der romanischen und germanischen Völker von 1494 bis 1514, Leipzig: Duncker u. Humblot, 1885 ( $3^{\text {rd }}$ ed.), p. 7 . 
egodocuments and self-narratives no longer can only be utilized under the condition that they contain "true" information, and that they are without value for historical inquiry if doubts exist about the veracity of their statements. As a consequence, working with egodocuments and self-narratives as bona fide sources has experienced a huge upsurge in recent decades. If in traditional or historicist historiography use was made principally of the memoirs or autobiographies of great statesmen, now the door was open to tapping the egodocuments and self-narratives of insignificant, ordinary persons, yes even those at times with little or no education, in order to analyze how the past was seen by them, how it was describable for them. ${ }^{56}$ At the same time, a new criticism developed of the older readings of egodocuments of various kinds. These readings now appeared to be naive, since they gullibly let themselves be taken in by the author's statements instead of critically interrogating the determinate character of those statements as a result of narrative structures and cultural contexts. ${ }^{57}$

Heinrich Witt has left us with a diary composed in a sober, objective indeed almost dry and unemotional style. Much data is set out in a highly regular and organized way and many explanations are extremely extensive, even obsessed with detail. The form of a diary creates the impression of immediacy and spontaneity in writing it down, even if we know that substantial sections of the diary were composed decades after the data therein described, and that the entire diary is a text based on previous notes or other texts and narratives. The consciously selected narrative structure of the text is in keeping with conventions of its time. In the $19^{\text {th }}$ century, quite large numbers of objective diaries were published dealing with everyday life or more lengthy trips, and which contain much information about political, cultural and social questions, but almost no mention or data concerning more intimate matters. ${ }^{58}$ Heinrich Witt thus makes use here of a style he likely knew and evidently had mastered. The degree of credibility we accord his statements springs in significant measure precisely from this style. On the one hand, it is the narrative of a private person, where matters to a certain extent are communicated tête-àtête, so to speak. On the other, what is conveyed is done in an objective way

$5^{6}$ Winfried Schulze, "Ego-Dokumente. Annäherung an den Menschen in der Geschichte? Vorüberlegungen für die Tagung 'Ego-Dokumente,'” in: idem. (ed.), Ego-Dokumente. Annäherung an den Menschen in der Geschichte, Berlin: Akademie-Verlag, 1996, pp. 11-30.

57 Dagmar Günther, “And now for something completely different'. Prolegomena zur Autobiographie als Quelle der Geschichtswissenschaft," Historische Zeitschrift, 272 (2001), pp. 25-61.

$5^{8}$ Steinitz, Time, Space, and Gender, p. 3. 
that enhances its credibility. So before one accepts Witt's statements at face value, one should ask why he narrates them in this form and why people think they are credible.

A central aspect of the narrative that serves to further and strengthen the credibility of Witt's statements in the reader's eyes is actually first constituted by the nature of the text itself: we know very little about Heinrich Witt's life aside from the actual diary. ${ }^{99}$ Thus, who he was is something we extract to a large measure from his self-presentation in the diary. Here Heinrich Witt styled himself in a quite ideal-typical manner as a citizen of the $19^{\text {th }}$ century. He is a white European male from one of the leading cities and nations of the world. As such, he is self-disciplined, independent, industrious, educated and conscientious. In the best Christian tradition, he is self-critical, and thus well aware that he also has weaknesses that he must admit and which he also has to deal with. The descriptions of these failings and weaknesses and also of typically human suffering thus underscore the great qualities of this individual rather than putting those evident qualities into question. The diary succeeds here exceptionally well in imbuing Witt's life both with coherence and individuality. Through the description of his background and the detailed discussion of and focus on his family, he describes himself as a link in the timeless chain. At the same time, through a detailed discussion and thematizing of his own self, he can describe his part in this familial succession as an individual and self-determined achievement. ${ }^{60}$

Yet Witt's diary is not only a presentation of his self but also a description of his time. Witt describes in part events that occurred many decades earlier, and in part things that only recently had come to pass. In this way, he creates his description of this time and era. This description, in its detailed quality and the linking of very different worlds (Altona, England, Peru) is exceedingly original and to a certain degree unique. But it is also marked and shaped by the time in which it was wrought. What Witt describes, how he describes and judges it, derives from his view of reality. Witt largely shared the prejudices, the racism and Eurocentrism of the elite in Lima stemming from Europe. He was

59 The most comprehensive and detailed description of Witt's life is Christa Wetzel, A Short Biography of Heinrich Witt.

6o "Nineteenth-century masculine autobiographers inscribe themselves within their texts as autonomous subjects free from the constraints of any social context." Martin A. Danahay, A Community of One. Masculine Autobiography and Autonomy in Nineteenth-Century Britain, New York: State University of New York Press, 1993, p. 7. A critique of biographical coherence can be found in Pierre Bourdieu, "Lillusion biographique," in: Actes de la recherche en sciences sociales, 62 (1986), pp. 69-72. 
shaped by northern German Protestantism, he admired European culture and patterns of behavior. That is reflected in his descriptions of things both in Peru and in Europe. The description of his world that Witt provides us achieves its value on the basis of his being an eye-witness to his times. But his judgments about contemporaries, events and conditions often tell us more about Witt and his character than about what he is actually describing. ${ }^{61}$

To read Witt's diary as a document shaped by its textual structure, Witt's culture and time does not mean to lessen its value. Even if it is often difficult to fully accept what Witt presents and describes on a one-to-one basis, and even if as a rule it is hardly possible to check out and verify his statements (because for many questions there simply are no other sources), we can in any case read the diary as Witt's description, his depiction and interpretation. The advantage Witt always has over us is that he himself also lived and breathed in the now distant times he describes.

61 On the interpretation of egodocuments and self-narratives from Peru in the $19^{\text {th }}$ and $20^{\text {th }}$ century, see Ulrich Mücke, Marcel Velázquez Castro (eds.), Autobiografía del Perú republicano. Ensayos sobre historia y la escritura del yo, Lima: Biblioteca Nacional del Perú, 2015. For an initial introduction to the topic, see Françoise Aubès, "Mémoires, autobiographies, journal intime: l'écriture de soi au Pérou," in: Anne Marie Brenot, Mémoires d'Amérique Latine. Correspondances, journaux intimes et récits de vie (XVII-XXèmes siècles), Frankfurt/M. and Madrid: Vervuert and Iberoamericana, 2009, pp. 163-172. 